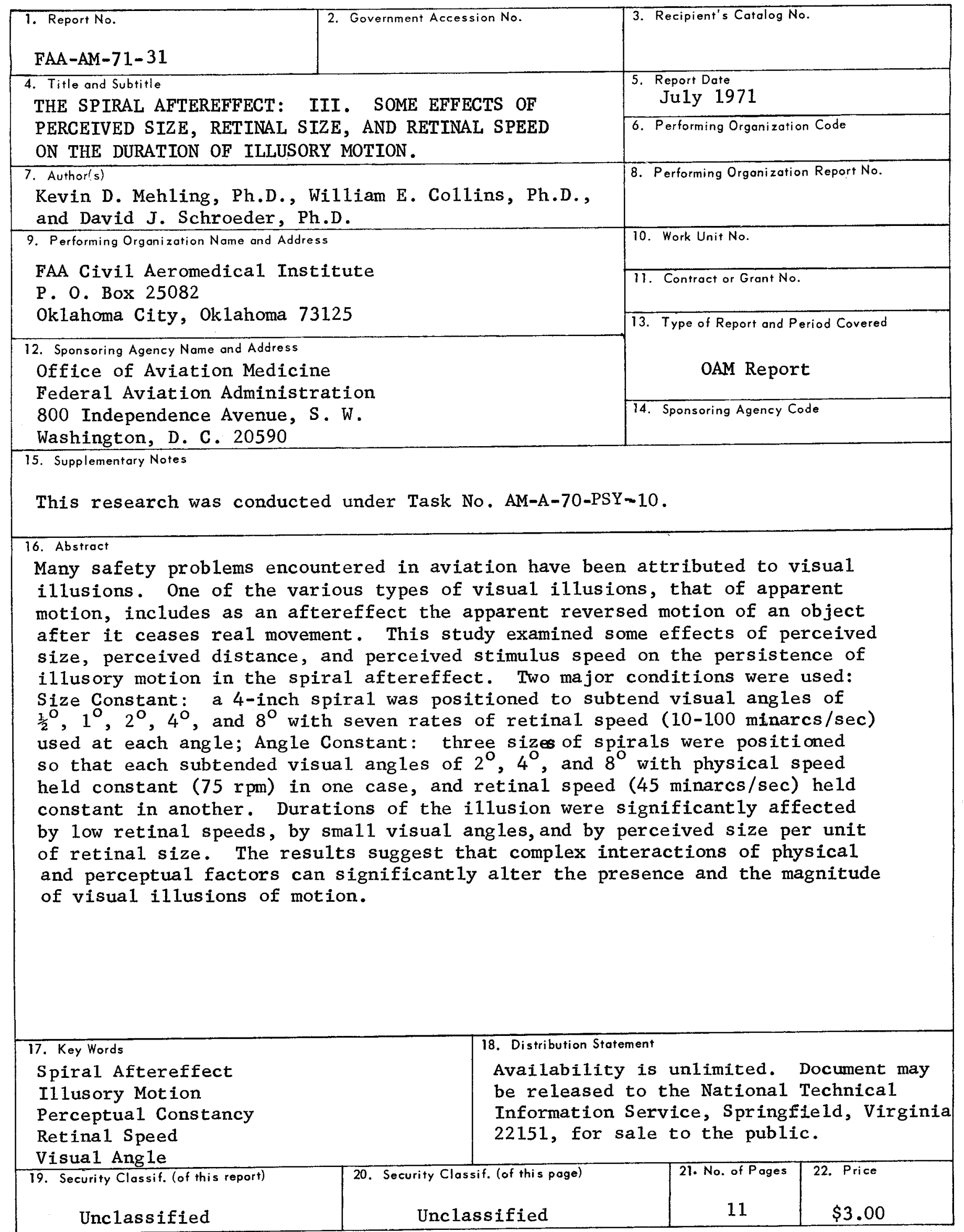

Form DOT F 1700.7 (8-69) 



\section{THE SPIRAL AFTEREFFECT: III. SOME EFFECTS OF PERCEIVED SIZE, RETINAL SIZE, AND RETINAL SPEED ON THE DURATION OF ILLUSORY MOTION}

\section{Introduction.}

Included among the areas which have been identified for the FAA as potentially capable of causing visual illusions to pilots is that of aftereffects. ${ }^{13}$ One of the various types of such visual illusions, that of apparent motion, has as an aftereffect the apparent reversed motion of an object after it ceases real movement. The present study was designed to examine the influence of some perceptual phenomena, viz. perceived size, perceived distance, and perceived stimulus speed, on the persistence of illusory motion.

Granit $^{8} 9$ contended that visual angle was an important determinant in the duration of motion aftereffect. He obtained peak duration scores for apparent motion (waterfall illusion) which increased from smaller angles to an optimal range $\left(2^{\circ}-4^{\circ}\right)$, and thereafter decreased as the angles became larger. Although several subsequent studiese.g., 31011 which used a relatively narrow range of stimuli did not confirm Granit's finding, supportive data appeared in the works of Pickersgill and Jeeves, ${ }^{12}$ Fozard, et al., ${ }^{2}$ and Collins and Schroeder. ${ }^{1}$

Granit $^{8}$ had also noted that changes in visual angle produced by moving the stimulus to different distances would affect retinal speed, i.e., as visual angle was increased by moving the stimulus closer to the subject, a given point on the stimulus would move through a greater retinal distance per unit of time. Scott and Noland ${ }^{14}$ felt that apparent discrepancies among the findings of several studies might be resolved by taking into account this retinal speed factor. They derived formulas for calculating the "speed of eliciting motion" (SEM) of rotating spirals, applied it to several sets of data, and concluded that the (spiral) aftereffect (SAE) increased for stimulating speeds up to 132 minarcs/sec and then declined.

Williams and Collins ${ }^{15}$ confirmed the peaking of SAE duration scores between $2^{\circ} 4^{\circ}$ of visual angle when the data were obtained at different distances using a single size of spiral rotating at a constant physical speed. However, no change in scores was obtained when several sizes of spiral were used at a single distance from the observer, and no difference was found for variations in SEM of as much as 50-200 minarcs/sec for a given angle. Of more significance, however, was the result obtained in an "angle constant" condition (several sizes of spirals placed at different distances, each subtending a $4^{\circ}$ visual angle); there was a statistically significant increase in SAE durations with the larger (and more distant) spirals in spite of the fact that visual angle, SEM, and physical speed of the stimulus were held constant. Williams and Collins ${ }^{15}$ hypothesized that factors associated with size constancy, i.e., perceptual characteristics of the stimulus situation, might account for these results.

Gogel and his colleagues ${ }^{4-7}$ have demonstrated the importance of various perceptual relationships on other apparently stimulus-determined phenomena in visual perception, such as simultaneous contrast. Thus, the present study was undertaken to determine the possible influences of perceived spiral size, distance, and speed on the duration of the spiral aftereffect across a range of visual angles in both "size constant" and "angle constant" conditions. Moreover, since the data of Williams and Collins ${ }^{15}$ suggested the possibility of some effects on SAE durations of SEMs below 50 minarcs/sec, a range of SEM from 10-100 minarcs/sec was examined at several visual angles. 


\section{Method.}

Subjects. The subjects were 14 paid, volunteer, male college students between the ages of 18 and 29. All subjects qualified on the Bausch and Lomb Ortho-rater according to criteria established for "Mechanics and Skilled Tradesmen" and, during the same qualifying session, were exposed to the spiral, made judgments of its size, distance, and speed, and signalled the duration of the aftereffect. The first 14 subjects so examined all met the visual qualifications and reported perception of the aftereffect.

Apparatus. All spirals were three-throw arithmetic spirals and only type A stimulation (real motion of contraction and aftereffect of expansion) was presented. The spirals were attached to a modified, shaft-driven, variable speed motor with four sets of gears. An electronic counter was used to calibrate and to provide constant monitoring of the speed of the spiral disc.

The motor was set on a wheeled cart, on one side of which was mounted a flat white plyboard screen ( $17 \times 18$ inches) which faced the observer and served as a viewing background. The visual alley was 48 feet in length and the sides were draped in white cloth. The floor was tiled in a white and gray checkerboard pattern and overhead fluorescent lighting was recessed in the ceiling. The stimulus was viewed from a head and chin rest which allowed a straight line of visual sight for the subject to fixate the center of the spiral.

Rotation of the spiral was timed by a Hunter timer set for a 15-second period for all stimuli. A modification of the motor brake provided instantaneous stopping of the rotating dises. The aftereffect was viewed by the subject on the inducing spiral-stimulus, and its duration was timed by means of a microswitch (which the subject depressed for the duration of the illusion) and a DC interval timer read in hundredths of seconds.

Pre and Post Trials. Several types of data were obtained during trials prior to and following each experimental session, using a 4-inch spiral which subtended a visual angle of $4^{\circ}$. The subject judged its size (diameter in inches) and distance (in feet) from him. This "standard" spiral was then rotated at $75 \mathrm{rpm}$ for 15 seconds; the subject judged its speed (in per- centage) and depressed the microswitch for the duration of the illusion. After a 3-minute rest interval, the spiral was set in motion again and the same judgments (perceived speed of the stimulus and duration of the aftereffect) were obtained. On each day, to provide the subject with a frame of reference for the perceived speed judgments, the spiral was first rotated at eight rpm; the subject was told that this represented "10 per cent" stimulus speed. Two minutes later, the spiral was rotated at $1280 \mathrm{rpm}$ and the subject was told that this represented " 100 per cent" stimulus speed. These Pre and Post trials permitted an evaluation of possible fatigue or habituation effects during the course of a single session and across the seven test days.

Procedure. Two major stimulus conditions were used: (spiral) Size Constant (first five days of experimentation) and (visual) Angle Constant (last two days of experimentation). Each experimental session (day) for a subject lasted from $1 \frac{1}{2}-2$ hours.

In the Size Constant condition, a 4-inch spiral was set at various distances to subtend visual angles of $1 / 2^{\circ}, 1^{\circ}, 2^{\circ}, 4^{\circ}$, or $8^{\circ}$. For each subject, all data for a given visual angle were obtained during a single session and the order of presentation of the five angle-sessions was random among subjects. Seven rates of retinal speed $(10,20,40,50,60,80$, and $100 \mathrm{minarcs} / \mathrm{sec})$ were presented for each visual angle in an order counterbalanced as much as possible among subjects, and among visual angles for a given subject. The range of physical speeds required to produce the various retinal speeds (SEM) was $8 \mathrm{rpm}$ (for $10 \mathrm{minarcs} / \mathrm{sec}$ at the $8^{\circ}$ angle) to $1280 \mathrm{rpm}$ (for $100 \mathrm{minarcs} / \mathrm{sec}$ at the $1 / 2^{\circ}$ angle). At each SEM setting, one judgment each of perceived size, distance, and stimulus speed was obtained from the subjects; however, three SAE duration measures were obtained. The latter followed exposures of 15 seconds to the rotating spiral and were separated by 3-minute rest intervals.

In the Angle Constant condition, an rpmconstant and an SEM-constant session were conducted; the order of presentation varied among the subjects. Three spiral sizes (4-, 10-, and 16-inch diameters) were used in each session; distances were varied so that each spiral could be set to subtend visual angles of $2^{\circ}, 4^{\circ}$, and $8^{\circ}$. 
The order of presentation of the spirals and the angle-settings were counterbalanced as much as possible among subjects. For each of the nine size-distance settings in a session, one judgment each of perceived size, distance, and stimulus speed, and three measures of the SAE duration were recorded. In the rpm-constant session, the physical speed of all stimuli was $75 \mathrm{rpm}$ (yielding SEM rates of $22.5,45$, and 90 minarcs/sec for the three visual angles); when SEM was held constant, the disc speed was varied to produce a constant retinal speed of $45 \mathrm{minares} / \mathrm{sec}$ (yielding physical speeds of 37.5, 75, and 150 rpm for the three visual angles).

\section{Results.}

The three duration scores obtained at each sizedistance-speed setting for each subject were averaged. Means and standard deviations of these values were calculated for the group at each experimental setting. The latter treatment was also applied to the single observations each of perceived size, perceived distance, and perceived stimulus speed obtained from the subjects at the various experimental settings.

Pre and Post Tests. No effects of habituation or fatigue were found in responses to the "standard" stimulus administered both prior and subsequent to each experimental session (see Table 1). The only finding of note in these data was the tendency for perceived stimulus speed to increase across days.

Perceived Size and Distance. The seven judgments (one prior to each SEM setting) each of spiral size and of distance made by a subject during a given (visual angle) session in the Size Constant condition were treated as replications (for many subjects, there was no variability) and were averaged to provide a single score for each subject under each visual angle condition. Means and standard deviations for the 14 subjects appear in Table 2. The diameter of the 4-inch spiral was consistently overestimated but was seen as essentially the same size (4.8-5.0

TABLE 1

Means and standard deviations for the duration, percelved speed, perceived distance, and perceived size of the "standard" spiral. (4"inch diameter, 4.77 feet from the observer, rotated at $75 \mathrm{rpm}$ ) used prior to and following the experimental trials on each of the seven days of experimentation.

\begin{tabular}{|c|c|c|c|c|c|c|c|c|c|}
\hline \multirow[b]{2}{*}{ Day } & & \multicolumn{2}{|c|}{$\begin{array}{l}\text { Duration } \\
\text { (seconds) } \\
\end{array}$} & \multicolumn{2}{|c|}{$\begin{array}{c}\text { Perceived } \\
\text { Speed (\%age) }\end{array}$} & \multicolumn{2}{|c|}{$\begin{array}{c}\text { Perceived } \\
\text { Size (inches) }\end{array}$} & \multicolumn{2}{|c|}{$\begin{array}{c}\text { Perceived } \\
\text { Distance (Feet) }\end{array}$} \\
\hline & & $\overrightarrow{\text { Pre }}$ & Post & Pre & Post & $\overline{\text { Pre }}$ & Post & Pre & Post \\
\hline 1 & $\begin{array}{l}M \\
S D\end{array}$ & $\begin{array}{r}18.16 \\
5.32\end{array}$ & $\begin{array}{r}15.92 \\
6.81\end{array}$ & $\begin{array}{r}26.07 \\
7.64\end{array}$ & $\begin{array}{r}27.14 \\
9.75\end{array}$ & $\begin{array}{l}4.71 \\
0.91\end{array}$ & $\begin{array}{l}4.79 \\
0.96\end{array}$ & $\begin{array}{l}3.86 \\
0.46\end{array}$ & $\begin{array}{l}3.96 \\
0.50\end{array}$ \\
\hline 2 & $\begin{array}{l}\mathrm{M} \\
\mathrm{SD}\end{array}$ & $\begin{array}{r}17.66 \\
6.30\end{array}$ & $\begin{array}{r}18.41 \\
8.98\end{array}$ & $\begin{array}{r}27.14 \\
7.26\end{array}$ & $\begin{array}{r}35.71 \\
9.38\end{array}$ & $\begin{array}{l}4.61 \\
1.04\end{array}$ & $\begin{array}{l}4.71 \\
1.19\end{array}$ & $\begin{array}{l}3.96 \\
0.50\end{array}$ & $\begin{array}{l}3.96 \\
0.50\end{array}$ \\
\hline 3 & $\begin{array}{l}\mathrm{M} \\
\mathrm{SD}\end{array}$ & $\begin{array}{r}15.07 \\
5.02\end{array}$ & $\begin{array}{r}15.79 \\
6.35\end{array}$ & $\begin{array}{r}28.21 \\
6.96\end{array}$ & $\begin{array}{l}32.86 \\
12.97\end{array}$ & $\begin{array}{l}5.07 \\
1.27\end{array}$ & $\begin{array}{l}5.11 \\
1.27\end{array}$ & $\begin{array}{l}4.07 \\
0.58\end{array}$ & $\begin{array}{l}4.04 \\
0.69\end{array}$ \\
\hline 4 & $\begin{array}{l}\mathrm{M} \\
\mathrm{SD}\end{array}$ & $\begin{array}{r}15.69 \\
5.24\end{array}$ & $\begin{array}{r}17.89 \\
7.59\end{array}$ & $\begin{array}{r}28.57 \\
5.69\end{array}$ & $\begin{array}{r}31.43 \\
8.86\end{array}$ & $\begin{array}{l}5.18 \\
1.27\end{array}$ & $\begin{array}{l}5.07 \\
1.14\end{array}$ & $\begin{array}{l}4.11 \\
0.56\end{array}$ & $\begin{array}{l}4.07 \\
0.55\end{array}$ \\
\hline 5 & $\begin{array}{l}\mathrm{M} \\
\mathrm{SD}\end{array}$ & $\begin{array}{r}17.37 \\
8.80\end{array}$ & $\begin{array}{r}16.54 \\
8.47\end{array}$ & $\begin{array}{r}28.93 \\
7.39\end{array}$ & $\begin{array}{l}33.93 \\
13.47\end{array}$ & $\begin{array}{l}5.14 \\
1.23\end{array}$ & $\begin{array}{l}5.07 \\
1.14\end{array}$ & $\begin{array}{l}4.04 \\
0.57\end{array}$ & $\begin{array}{l}4.04 \\
0.57\end{array}$ \\
\hline 6 & $\begin{array}{l}\mathrm{M} \\
\mathrm{SD}\end{array}$ & $\begin{array}{r}14.76 \\
7.46\end{array}$ & $\begin{array}{r}18.51 \\
8.87\end{array}$ & $\begin{array}{r}29.29 \\
7.81\end{array}$ & $\begin{array}{l}38.57 \\
14.34\end{array}$ & $\begin{array}{l}5.07 \\
1.07\end{array}$ & $\begin{array}{l}4.57 \\
1.07\end{array}$ & $\begin{array}{l}4.04 \\
0.57\end{array}$ & $\begin{array}{l}4.36 \\
1.18\end{array}$ \\
\hline 7 & $\begin{array}{l}\mathrm{M} \\
\mathrm{SD}\end{array}$ & $\begin{array}{r}17.21 \\
8.77\end{array}$ & $\begin{array}{r}18.45 \\
7.46\end{array}$ & $\begin{array}{r}32.14 \\
8.02\end{array}$ & $\begin{array}{l}36.79 \\
15.14\end{array}$ & $\begin{array}{l}4.79 \\
0.98\end{array}$ & $\begin{array}{l}4.71 \\
0.99\end{array}$ & $\begin{array}{l}4.14 \\
0.60\end{array}$ & $\begin{array}{l}4.14 \\
0.60\end{array}$ \\
\hline
\end{tabular}


inches) across the five visual angles. Distance was slightly, but consistently, underestimated and the relationship of perceived to physical values was roughly proportional.

Similar results were obtained in the Angle Constant condition (Table 3). Spiral diameters were consistently overestimated (even though they subtended the same visual angle) and distances were slightly underestimated (but were approximately proportional to actual distances). Judgments of a given spiral diameter were not significantly affected by the visual angle which it subtended.

TABLE 2

Means and standard deviations for the size and distance

judgments made in the Size Constant Condition.

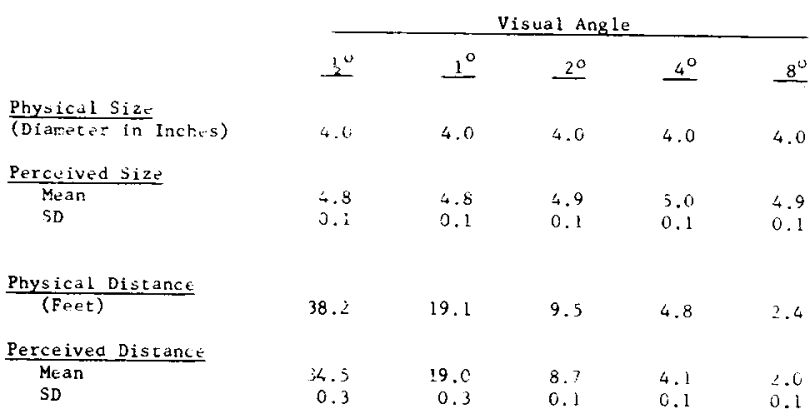

TABLE 3

Means and standard deviations for the size and distance

judgments made in the RPM-constant and SEM-constant

sessions of the Angle Constant Condition.

\begin{tabular}{|c|c|c|c|c|c|c|}
\hline \multirow{3}{*}{$\begin{array}{l}\text { Spiral } \\
\text { Diameter } \\
\text { (inches) }\end{array}$} & \multirow{3}{*}{$\begin{array}{l}\text { Physical } \\
\text { Distance } \\
\text { (feet) }\end{array}$} & & \multicolumn{4}{|c|}{$2^{\circ}$ Visual Angle } \\
\hline & & & \multicolumn{2}{|c|}{ Perceived Size } & \multicolumn{2}{|c|}{ Perceived Distance } \\
\hline & & & & & $\underline{\mathrm{Ax} n}$ & $\underline{\mathrm{SEM}}$ \\
\hline \multirow[t]{2}{*}{4} & \multirow[t]{2}{*}{9.5} & $M$ & 4.8 & 4.9 & 8.8 & 9.0 \\
\hline & & SD & 1.1 & 1.0 & 1.5 & 1.8 \\
\hline \multirow[t]{2}{*}{10} & \multirow[t]{2}{*}{23.8} & M & 12.4 & 12.0 & 21.9 & 21.0 \\
\hline & & SD & 3.1 & 2.3 & 4.5 & 3.4 \\
\hline \multirow[t]{3}{*}{16} & \multirow[t]{3}{*}{38.2} & M & 18.2 & 18.9 & 34.5 & 33.6 \\
\hline & & SD & 3.7 & 3.4 & 8.8 & 6.1 \\
\hline & & & \multicolumn{4}{|c|}{$4^{\circ}$ Visual Angle } \\
\hline \multirow[t]{2}{*}{4} & \multirow[t]{2}{*}{4.8} & $M$ & 4.6 & 4.7 & 4.0 & 4.1 \\
\hline & & SD & 1.0 & 1.0 & 0.6 & 0.7 \\
\hline \multirow[t]{2}{*}{10} & \multirow[t]{2}{*}{11.9} & M & 12.2 & 12.8 & 11.4 & 11.1 \\
\hline & & SD & 3.0 & 3.4 & 2.7 & 1.9 \\
\hline \multirow[t]{3}{*}{16} & \multirow[t]{3}{*}{19.1} & M & 19.1 & 19.1 & 17.4 & 19.0 \\
\hline & & SD & 4.2 & 3.9 & 2.8 & 3.2 \\
\hline & & & \multicolumn{4}{|c|}{$8^{\circ}$ Visual Angle } \\
\hline \multirow[t]{2}{*}{4} & \multirow[t]{2}{*}{2.4} & M & 4.8 & 4.5 & 2.0 & 1.9 \\
\hline & & SD & 1.0 & 1.1 & 0.2 & 0.3 \\
\hline \multirow[t]{2}{*}{10} & \multirow[t]{2}{*}{6.0} & M & 11.6 & 12.4 & 5.3 & 5.5 \\
\hline & & SD & 2.4 & 2.8 & 0.7 & 1.4 \\
\hline \multirow[t]{2}{*}{16} & \multirow[t]{2}{*}{9.5} & M & 18.1 & 19.3 & 9.5 & 9.2 \\
\hline & & SD & 3.2 & 3.6 & 2.7 & 1.9 \\
\hline
\end{tabular}
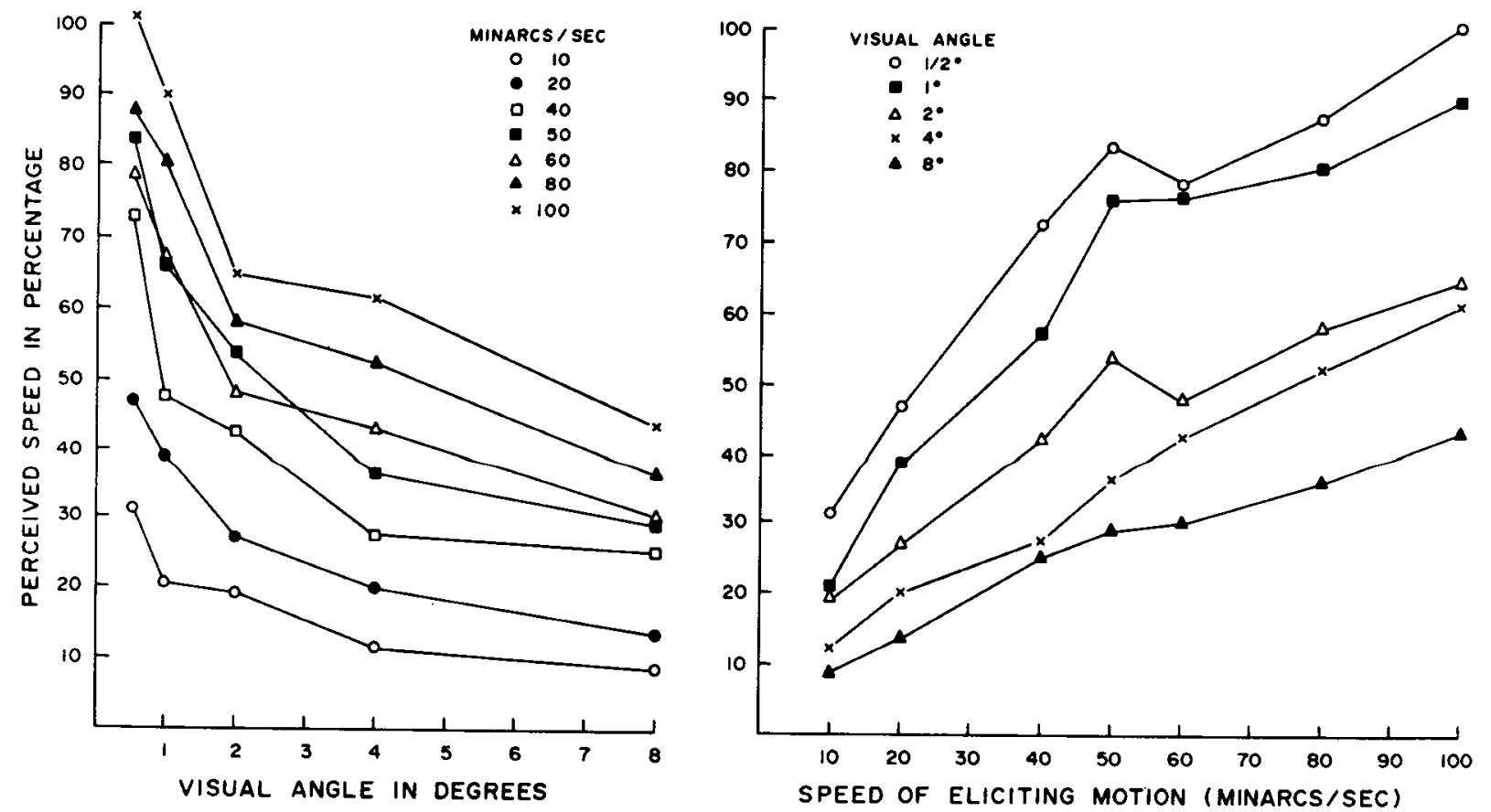

Figure 1. Perceived Speed (in percentage) as a function of visual angle and speed of eliciting motion in the Size Constant condition. 


\section{Perceived Speed}

Size Constant Condition. Mean perceived speed responses for the 14 subjects were plotted in Figure 1. For a given visual angle, increases in retinal speed (and physical speed) generally yielded higher ratings of perceived speed. With retinal speed (minarcs/sec) held constant, increasing the visual angle (moving the spiral closer to the subject and reducing the physical speed) invariably resulted in lower ratings of perceived speed. Thus, ratings of stimulus speed were determined primarily by physical speed in this condition.

Angle Constant Condition. Group mean perceived speed responses were plotted in Figure 2. In both the rpm-constant and SEM-constant sessions, there was essentially no difference in the perceived speed of the three spiral sizes when they subtended the same visual angle (none might be expected since visual angle, rpm, and SEM were all constant). An analysis of variance

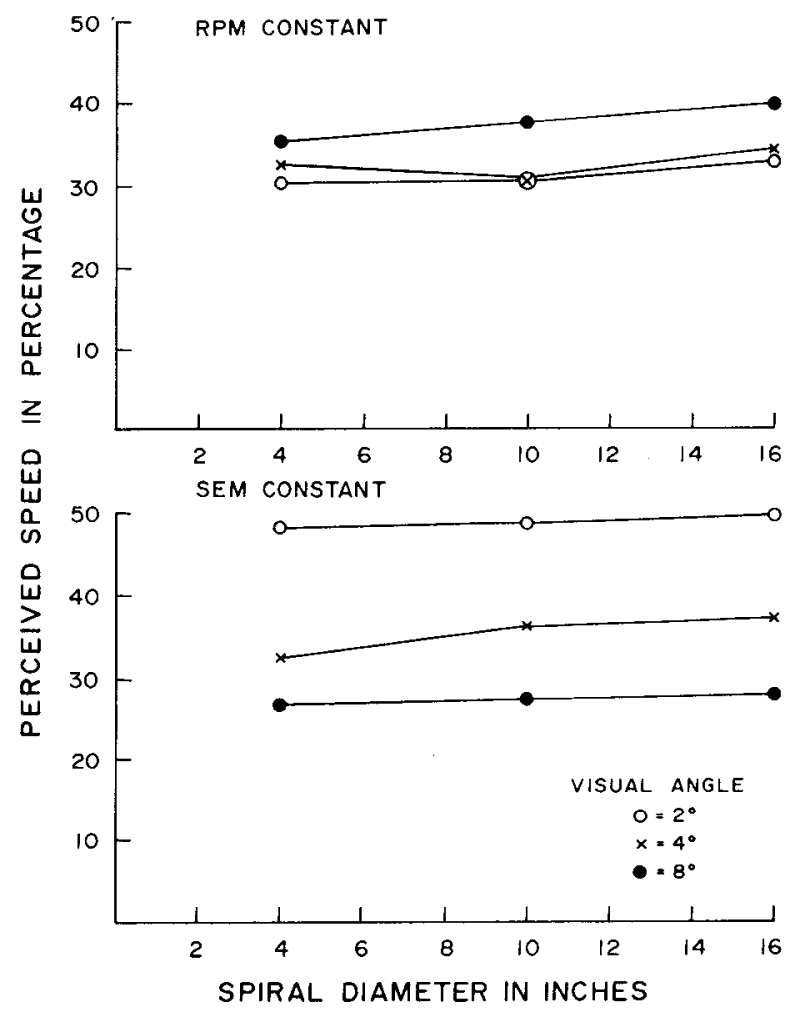

Figure 2. Perceived Speed (in percentage) as a function of three spiral sizes (4-, 10-, and 16-inch diameters) for three visual angles $\left(2^{\circ}, 4^{\circ}\right.$, and $\left.8^{\circ}\right)$ in the RPM Constant Session and in the Minarcs/ Sec Constant Session of the Angle Constant condition. yielded significant $\mathrm{F}$ ratios for sessions $(.05$ level), angles (.001 level), and the session by angle interaction (.001 level). Results of $t$ tests indicated that, in the rpm-constant session, perceived speed was significantly faster $(.05$ to .001 levels) for a given spiral size at the $8^{\circ}$ angle than at either the $2^{\circ}$ or $4^{\circ}$ angle (with the exception of the $4^{\circ}$ vs. $8^{\circ}$ comparison with the 4 -inch spiral). For no spiral size did the perceived speed judgments differ significantly between $2^{\circ}$ and $4^{\circ}$ for a given spiral size.

In the SEM-constant session, $\mathrm{t}$ tests indicated that, for each spiral size, increasing the visual angle (and decreasing the physical speed) from $2^{\circ}$ to $4^{\circ}$ to $8^{\circ}$ produced statistically significant (.01 to .001 levels) reductions in perceived speed. Thus, although perceived stimulus speed depended primarily upon the physical speed of the stimulus (Size Constant condition and SEMconstant session of the Angle Constant condition), a lesser effect, but a significant one, could be attributed to retinal speed (rpm-constant session of the Angle Constant condition).

\section{SAE Duration}

Size Constant Condition. SAE means and SDs for the seven SEM rates at each of the five visual angles appear in Table 4 and plots of the data are presented in Figures 3 and 4. Clear peaking effects are apparent between $2^{\circ}-4^{\circ}$ of visual angle for SEM values ranging from 40

TABLE 4

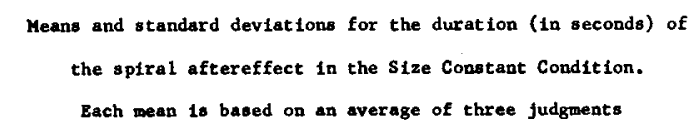

for each of 14 subjects.

\begin{tabular}{|c|c|c|c|c|c|c|}
\hline \multirow{2}{*}{$\frac{\text { SEM }}{\text { Minares } / \text { sec }}$} & & \multicolumn{5}{|c|}{ Visual Angle } \\
\hline & & $\frac{1}{2}^{\circ}$ & $1^{\circ}$ & $2^{\circ}$ & $4^{\circ}$ & $8^{\circ}$ \\
\hline 10 & $\begin{array}{l}M \\
S D\end{array}$ & $\begin{array}{r}15.25 \\
6.96\end{array}$ & $\begin{array}{r}12.49 \\
5.29\end{array}$ & $\begin{array}{r}12.92 \\
5.50\end{array}$ & $\begin{array}{r}11.49 \\
5.25\end{array}$ & $\begin{array}{r}10.51 \\
5.79\end{array}$ \\
\hline 20 & $\begin{array}{l}\text { M } \\
\text { SD }\end{array}$ & $\begin{array}{r}16.35 \\
5.36\end{array}$ & $\begin{array}{r}16.82 \\
5.56\end{array}$ & $\begin{array}{r}16.88 \\
5.86\end{array}$ & $\begin{array}{r}16.38 \\
6.92\end{array}$ & $\begin{array}{r}11.53 \\
5.91\end{array}$ \\
\hline 40 & $\begin{array}{l}\text { M } \\
\text { SD }\end{array}$ & $\begin{array}{r}17.12 \\
6.00\end{array}$ & $\begin{array}{r}19.46 \\
6.06\end{array}$ & $\begin{array}{r}20.51 \\
6.08\end{array}$ & $\begin{array}{r}20.07 \\
8.74\end{array}$ & $\begin{array}{r}14.92 \\
8.21\end{array}$ \\
\hline 50 & $\begin{array}{l}M \\
\text { SD }\end{array}$ & $\begin{array}{r}17.68 \\
7.96\end{array}$ & $\begin{array}{r}19.63 \\
4.93\end{array}$ & $\begin{array}{r}19.87 \\
4.87\end{array}$ & $\begin{array}{r}20.36 \\
8.01\end{array}$ & $\begin{array}{r}15.63 \\
7.25\end{array}$ \\
\hline 60 & $\begin{array}{l}M \\
S D\end{array}$ & $\begin{array}{r}16.52 \\
5.99\end{array}$ & $\begin{array}{r}17.99 \\
4.93\end{array}$ & $\begin{array}{r}20.52 \\
4.04\end{array}$ & $\begin{array}{r}20.01 \\
7.71\end{array}$ & $\begin{array}{r}15.84 \\
7.28\end{array}$ \\
\hline 80 & $\begin{array}{l}M \\
\text { SD }\end{array}$ & $\begin{array}{r}15.83 \\
5.95\end{array}$ & $\begin{array}{r}16.81 \\
5.67\end{array}$ & $\begin{array}{r}19.62 \\
4.85\end{array}$ & $\begin{array}{r}20.30 \\
7.38\end{array}$ & $\begin{array}{r}15.88 \\
7.54\end{array}$ \\
\hline 100 & $\begin{array}{l}M \\
\text { SD }\end{array}$ & $\begin{array}{r}12.25 \\
5.43\end{array}$ & $\begin{array}{r}15.82 \\
6.64\end{array}$ & $\begin{array}{r}21.24 \\
5.69\end{array}$ & $\begin{array}{r}20.19 \\
7.41\end{array}$ & $\begin{array}{r}17.56 \\
8.50\end{array}$ \\
\hline
\end{tabular}




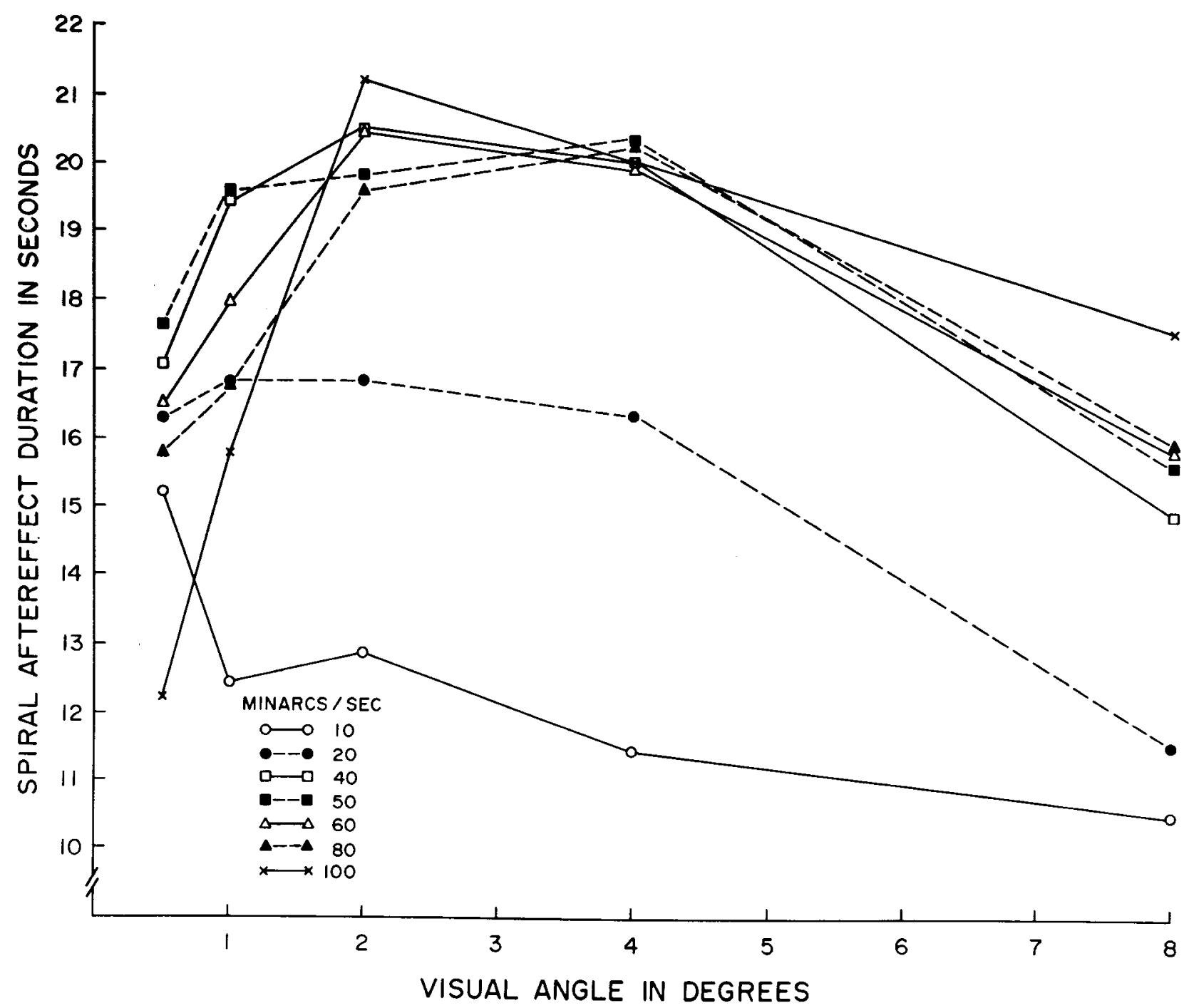

FrgURE 3. Duration of the spiral aftereffect in seconds as a function of Visual Angle for seven speeds of eliciting motion in the Size Constant condition.

through $100 \mathrm{minarcs} / \mathrm{sec}$; a general flattening appears in the plot of $20 \mathrm{minarcs} / \mathrm{sec}$ from $1^{\circ}-4^{\circ}$ with the duration score declining considerably from $4^{\circ}-8^{\circ}$, while in the $10 \mathrm{minarcs} / \mathrm{sec}$ plot, there is a general decline from $1 / 2^{\circ}-8^{\circ}$ (see Figure 3 ). The same data were plotted differently in Figure 4 to show the effect on duration scores of varying SEM at each visual angle. For all angles, SAE durations increased as SEM increased from 10 through 40 minarcs/sec. For visual angles of $2^{\circ}, 4^{\circ}$, and $8^{\circ}$, no further effect on duration scores occurred as SEM was increased from 40 to $100 \mathrm{minarcs} / \mathrm{sec}$. However, at the two smallest angles $\left(12^{\circ}\right.$ and $\left.1^{\circ}\right)$, peak $\mathrm{SAE}$ durations were obtained at $50 \mathrm{minarcs} / \mathrm{sec}$, followed by a steady decline with increasing rates of SEM (see Figure 4); at least part of this decline can probably be attributed to some stimulus blurring at the high rates of physical speed required (1280 $\mathrm{rpm}$ for $100 \mathrm{minarcs} / \mathrm{sec}$ at $1 / 2^{\circ}$ ).

An analysis of variance yielded statistically significant differences (.01-.001 levels) for SAE duration scores among the five visual angles and among the seven SEM rates, as well as for the visual angle by retinal speed interaction. $t$ tests indicated that, in all but one case (20 vs. 40 minarcs/sec for the $1 / 2^{\circ}$ angle), the lower SEM rates produced significantly shorter (.05 to .001 levels) SAE durations than those obtained at 40 


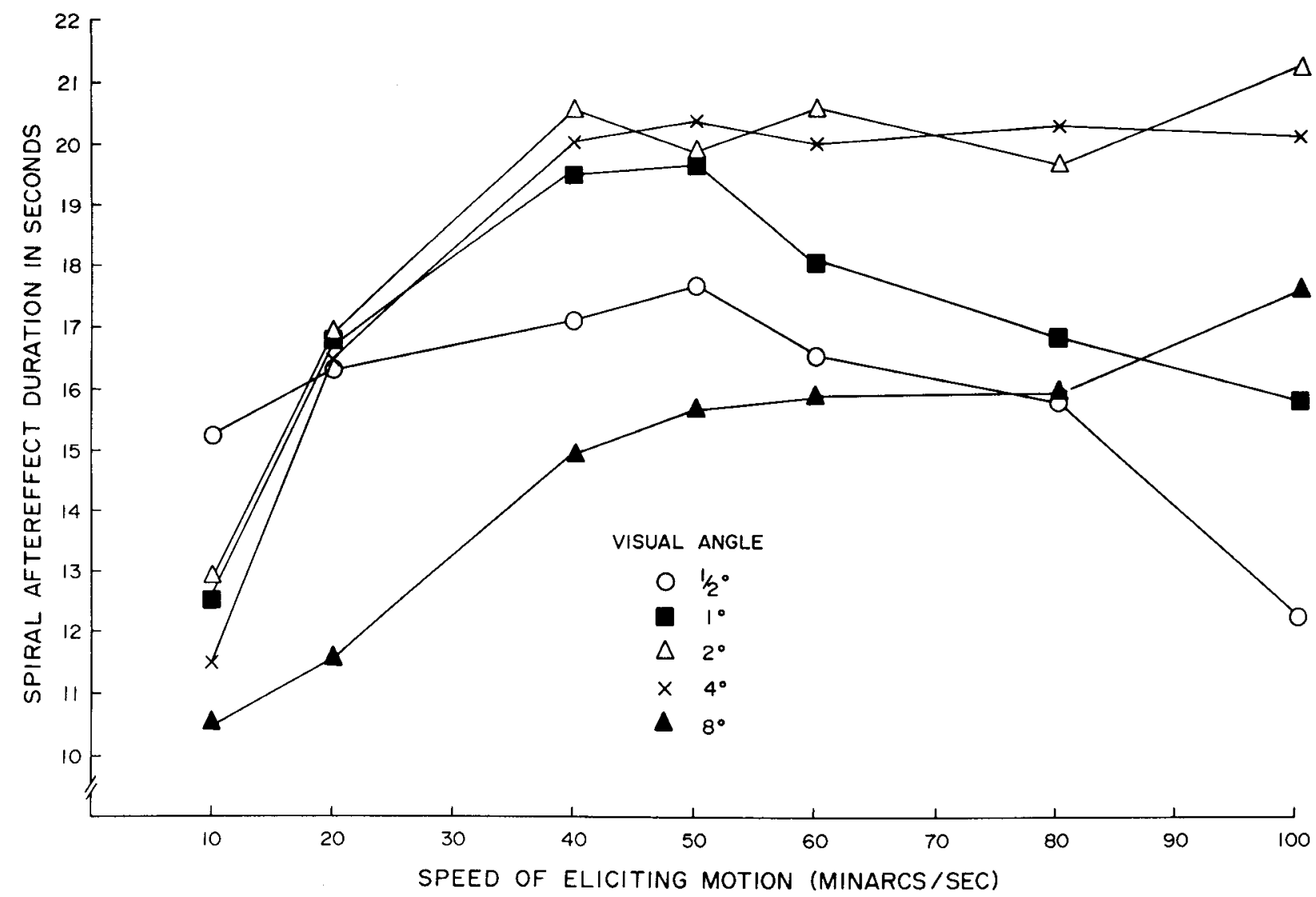

FIGURE 4. Duration of the spiral aftereffect in seconds as a function of the speed of eliciting motion for five visual angles in the Size Constant condition.

minarcs/sec (in the case of the exception, the difference, though not significant, was in the same direction). Comparisons between 40 and $100 \mathrm{minarcs} / \mathrm{sec}$ indicated no change in duration scores for angles of $2^{\circ}, 4^{\circ}$, and $8^{\circ}$. However, declines in duration from 40 to $100 \mathrm{minarcs} / \mathrm{sec}$ for the two smallest angles $12^{\circ}$ and $1^{\circ}$ ) were significant (.01 and .001 levels).

TABLE 5

Means and standard deviations for the duration (in seconds) of the spiral aftereffect in the Angle Constant Condition.

Each mean is based on an average of three judgments for each of 14 subjects.

\begin{tabular}{|c|c|c|c|c|c|c|c|}
\hline \multirow{3}{*}{$\begin{array}{l}\text { Visual } \\
\text { Angle }\end{array}$} & & \multicolumn{6}{|c|}{ Spiral Diameter (inches) } \\
\hline & & \multicolumn{3}{|c|}{ RPM Constant } & \multicolumn{3}{|c|}{ SEM Constant } \\
\hline & & 4 & 10 & 16 & 4 & 10 & 16 \\
\hline $2^{0}$ & $\begin{array}{l}\mathrm{M} \\
\mathrm{sp}\end{array}$ & $\begin{array}{r}16.65 \\
6.29\end{array}$ & $\begin{array}{r}18.18 \\
5.74\end{array}$ & $\begin{array}{r}19.00 \\
6.50\end{array}$ & $\begin{array}{r}18.90 \\
6.77\end{array}$ & $\begin{array}{r}19.95 \\
6.68\end{array}$ & $\begin{array}{r}21.62 \\
7.30\end{array}$ \\
\hline $4^{\circ}$ & $\begin{array}{l}M \\
\text { SD }\end{array}$ & $\begin{array}{r}17.16 \\
8.65\end{array}$ & $\begin{array}{r}19.92 \\
8.51\end{array}$ & $\begin{array}{r}20.26 \\
8.84\end{array}$ & $\begin{array}{r}16.94 \\
7.19\end{array}$ & $\begin{array}{r}20.13 \\
7.94\end{array}$ & $\begin{array}{r}20.87 \\
6.95\end{array}$ \\
\hline $8^{\circ}$ & $\begin{array}{l}M \\
S D\end{array}$ & $\begin{array}{r}16.55 \\
9.00\end{array}$ & $\begin{array}{r}18.80 \\
7.71\end{array}$ & $\begin{array}{r}19.17 \\
8.58\end{array}$ & $\begin{array}{r}13.84 \\
8.54\end{array}$ & $\begin{array}{r}16.47 \\
8.39\end{array}$ & $\begin{array}{r}18.36 \\
7.06\end{array}$ \\
\hline
\end{tabular}

Angle Constant Condition. SAE means and SDs for the various spiral sizes used to produce three settings each of $2^{\circ}, 4^{\circ}$, and $8^{\circ}$ appear in Table 5 and plots of the data for both the rpmconstant and the SEM-constant sessions are in Figure 5. For each angle and in both sessions, duration scores increased as the spiral diameter increased in size from 4 to 10 to 16 inches.

An analysis of variance yielded significant effects (.05-.001 levels) among visual angles and spiral diameters, between sessions, and for the session by visual angle interaction. $t$ tests for the rpm-constant session showed that only at the $4^{\circ}$ angle was there a statistically significant difference in SAE duration among spiral sizes; the 4-inch spiral yielded shorter durations than either the 10-inch (.05 level) or the 16-inch (.01 level) stimulus. For the SEM-constant session, $\mathrm{t}$ tests yielded significantly lower (.01-.001 levels) duration scores for the 4- vs. 16-inch spirals at all visual angles, and significant differences (.05-.01 levels) for four of the remaining six comparisons among spiral sizes. 




Figure 5. Duration of the spiral aftereffect in seconds as a function of three spiral sizes (4-, 10-, and 16-inch diameters) for the three visual angles $\left(2^{\circ}, 4^{\circ}\right.$, and $\left.8^{\circ}\right)$ in the RPM Constant session and in the Minarcs/Sec Constant session of the Angle Constant condition.

\section{Relationship Between SAE Durations and Other Perceptual Data}

Comparisons of Figure 1 with Figures 3 and 4, and of Figure 2 with Figure 5 indicate clearly that the plotted SAE data cannot be accounted for on the basis of perceived speed. However, perceived size measures were converted into ratios of the perceived size $\left(S^{\prime}\right)$ of the spiral per unit of retinal size $(\theta)$. This ratio was plotted against perceived distance for both the Size Constant and Angle Constant conditions; $\mathrm{S}^{\prime} / \theta$ was equivalent to perceived distance as suggested in the "Size-Distance Invariance Hypothesis." The SAE durations were then plotted against $\mathrm{S}^{\prime} / \theta$ for the Size Constant and for the Angle Constant conditions (Figures 6 and 7 ). 


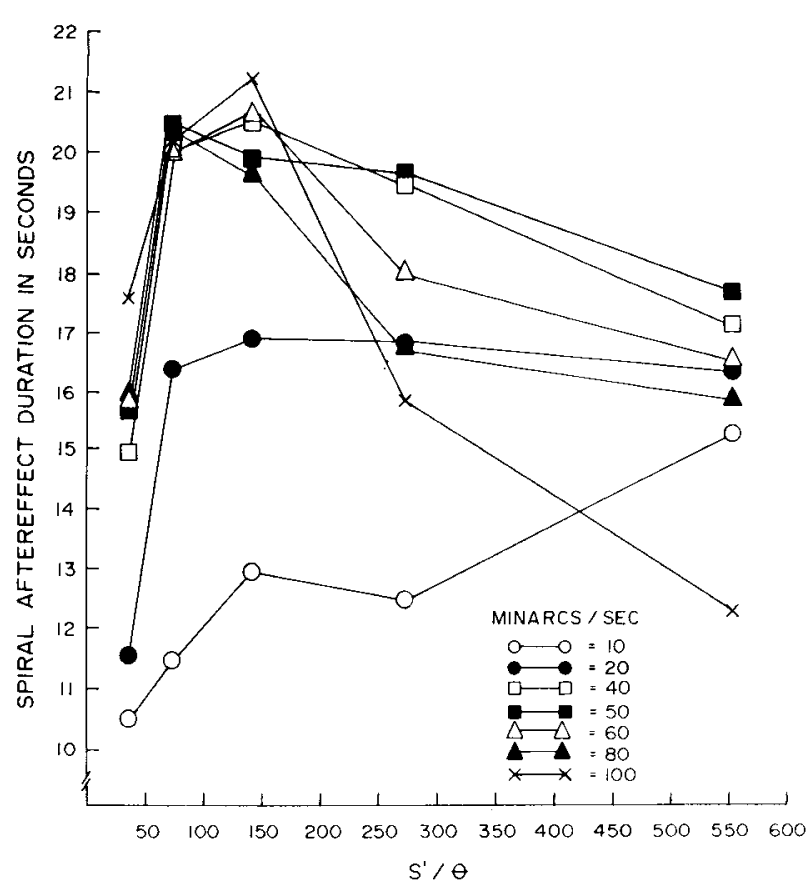

Figure 6. Duration of the spiral aftereffect in seconds as a function of the ratio $\left(S^{\prime} / \theta\right)$ of perceived size (in inches) per unit of retinal size (in radians) for seven speeds of eliciting motion in the Size Constant condition.

For the Size Constant data (Figure 6), SAE scores increased as $\mathrm{S}^{\prime} / \theta$ increased from $8^{\circ}$ through $2^{\circ}$ of visual angle. At smaller angles, however, there was a decline in duration scores, although $\mathrm{S}^{\prime} / \theta$ continued to increase; the decline from $2^{\circ}$ to $1 / 2^{\circ}$ of visual angle was statistically significant (.05 to .001 levels) for four of the seven SEM rates. With respect to the Angle Constant condition (Figure 7), SAE scores increased as $S^{\prime} / \theta$ increased. However, the results differed somewhat depending upon whether rpm or SEM was held constant. In the former case, three obviously separate plots were generated (one for each visual angle); in the latter case, the data points for the three visual angles more closely approximate a monotonic function. Thus, factors associated with size constancy principles do not totally account for these changes in SAE duration scores.

\section{Discussion.}

Retinal Size. These data indicate important interactions of perceptual and physical factors on the duration of the spiral aftereffect. The Angle Constant condition shows clear effects of the perceived size of the spiral (per unit of retinal size) on duration judgments. Although
$S^{\prime} / \theta$ appears to be the primary influence on those scores, the equation seems somewhat more predictive of duration values across a range of visual angles when SEM is held constant (Figure 7).

However, $S^{\prime} / \theta$ is only partially effective in explaining the changes in SAE duration across visual angles in the Size Constant condition, since peaking effects were generally observed between $2^{\circ}-4^{\circ}$ despite constant SEM rates. By combining the results from Williams and Collins ${ }^{15}$ with those of the present study, SAE durations can be said to increase as $S^{\prime} / \theta$ increases from $16^{\circ}$ to $2^{\circ}$ of visual angle, but this relationship does not hold for angles smaller than $2^{\circ}$. The failure of duration scores to increase with increases of $\mathrm{S}^{\prime} / \theta$ at visual angles less than $2^{\circ}$ cannot lie in a breakdown of the ratio at high values since SAE durations increased throughout the

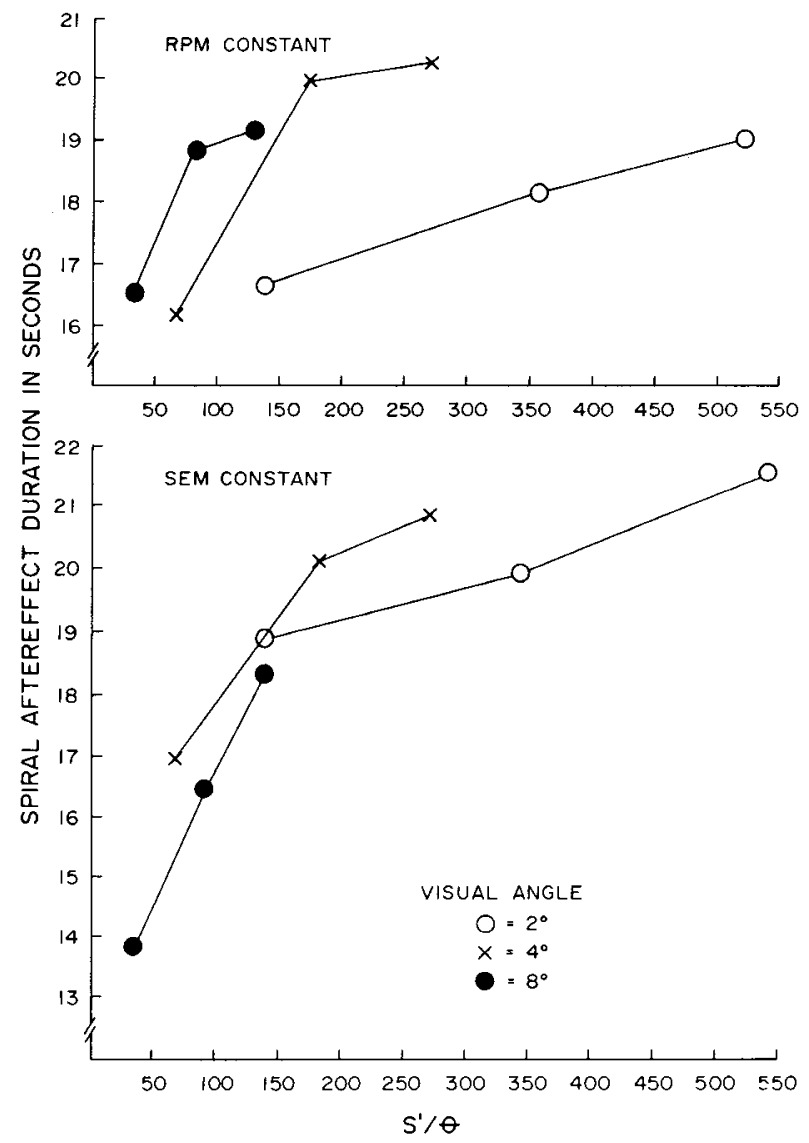

Figure 7. Duration of the spiral aftereffect in seconds as a function of the ratio $\left(S^{\prime} / \theta\right)$ of perceived size (in inches) per unit of retinal size (in radians) for three spiral sizes (4-, 10-, and 16-inch diameters) for each of three visual angles $\left(2^{\circ}, 4^{\circ}\right.$, and $\left.8^{\circ}\right)$ for the RPM Constant and the Minarcs/Sec Constant sessions in the Angle Constant condition. 
$S^{\prime} / \theta$ range in the Angle Constant condition but, for the same $S^{\prime} / \theta$ range in the Size Constant condition, duration scores decreased at visual angles of $1 / 2^{\circ}$ and $1^{\circ}$.

Several possibilities might be offered to explain the peaking effect, but there are available too few data to support adequately any single explanation. What seems clear is that $\mathrm{S}^{\prime} / \theta$ has significant predictive value for spiral aftereffect durations within specified conditions, but other experiments are required to define the basis for these limits since interactions clearly occur.

Retinal Speed. Scott and Noland ${ }^{14}$ suggested that some changes in SAE durations could be accounted for in items of retinal speed. From several sets of data, they concluded that SAE durations would increase from 30-132 minarcs/sec and then decline. However, data from Collins and Schroeder ${ }^{1}$ and Williams and Collins ${ }^{15}$ did not agree with this range. For example, the latter study showed no effect on duration scores of SEMs between 50-200 minarcs/sec under two sets of conditions, but other data led the authors to suggest that retinal speeds below 50 minares/ sec might have differential effects on SAE durations.

The present results confirm the notion that SAE duration scores are differently affected (they increase) as SEM values increase up to 40 minarcs/sec, but no significant effect was found upon SAE durations over a range of SEM values from 40 to $100 \mathrm{minarcs} / \mathrm{sec}$ for the $2^{\circ}, 4^{\circ}$, and $8^{\circ}$ visual angles. Although there was a significant decline in SAE duration between 40 and 100 minarcs/sec for the $1 / 2^{\circ}$ and $1^{\circ}$ angles, at least two contributing factors can be cited for these declines: (a) The physical speeds necessary to maintain 100 minares/sec for these angles were very high and, regardless of retinal speed, characteristics of the stimulus were changed, i.e., blurring occurred; (b) in addition, there are many fewer retinal elements available effectively to respond to very high stimulus rates at these angle sizes.

There are indications (Figures 3 and 7) that SEM may have important, but limited, utility in analyzing patterns of change among SAE duration scores. However, as with the influence of size constancy factors, other experiments are needed to define the extent of the contribution made by retinal speed as well as the limits of its effectiveness in producing change in SAE duration.

It has been suggested elsewhere ${ }^{13}$ that illusory motion, such as that obtained in the spiral aftereffect, might be most evident in flight situations in some variations of close-in formations and cloud mist conditions. "For example, it is possible that a pilot operating close to the top of a stratus layer and who had been seeing the clouds running by beneath him for some time were then to lift his gaze and detect another aircraft operating in the vicinity, the opposing airplane would be seen to recede. This effect would be particularly undesirable if the aircraft was, in fact, closing on him." ${ }^{13}$ Results from the present study point to complex interactions of physical and perceptual factors which can significantly alter the presence and the magnitude of such visual illusions. 


\section{REFERENCES}

1. Collins, W. E. and D. J. Schroeder: Some Effects of Changes in Spiral Size and Viewing Distance on the Duration of the Spiral Aftereffect, PERCEPTUAL AND MOTOR SKILLS, $27: 119-126,1968$.

2. Fozard, J. L., M. Fuchs, M. Palmer, and A. M. Smith: Effect of Combinations of Six Presentation Conditions on the Duration of the Spiral Aftereffect. U.S. Government R \& D Report, AD-623-976 (Dec.), 1965.

3. Freud, S. L.: Duration of Spiral Aftereffect as a Function of Retinal Size, Retinal Place, and HemiRetinal Transfer, PERCEPTUAL AND MOTOR SKILLS, $18: 47-53$, 1964.

4. Gogel, W. C.: Perception of Depth from Binocular Disparity, JOURNAL OF EXPERIMENTAL PSYCHOLOGY, 67 :379-386, 1964.

5. Gogel, W. C. and D. H. Mershon: The Perception of Size in a Distorted Room, PERCEPTION AND PSYCHOPHYSICS, $4: 26-28,1968$.

6. Gogel, W. C. and D. H. Mershon: Depth Adjacency in Simultaneous Contrast, PERCEPTION AND PSYCHOPHYSICS, $5: 13-17,1969$.

7. Gogel, W. E. and H. W. Mertens: Perceived Depth Between Familiar Objects, JOURNAL OF EXPERIMENTAL PSYCHOLOGY, $77: 206-211,1968$.
8. Granit, R.: Ueber eine Hemmung der Zapfenfunktion durch Staebchenerregung beim Bewegungsnachbild, ZEITSCHRIFT FUER SINNESPHYSIOLOGIE, $58: 95-110,1927$.

9. Granit, R.: On Inhibition in the After-Effect of Seen Movement, BRITISH JOURNAL OF PSYCHOLOGY, $19: 147-157,1928$.

10. Holland, H. C.: Some Determinants of Seen Aftermovements in the Archimedes Spiral, ACTA PSYCHOLOGICA (Amsterdam), $14: 215-222,1958$.

11. Holland, H. C.: The Spiral After-effect, Vol. 2. International Series of Monographs in Experimental Psychology, New York, Pergamon Press, 1965.

12. Pickersgill, M. J. and M. A. Jeeves: After-effect of Movement Produced by a Rotating Spiral, NATURE, $182: 1820,1958$.

13. Rowland, G. E. and J. F. Snyder: Visual Illusion Problems. FAA RD Report No. 69-49, September, 1970.

14. Scott, T. R. and J. H. Noland: Some Stimulus Dimensions of Rotating Spirals, PSYCHOLOGICAI, REVIEW, $72: 344-357,1965$.

15. Williams, M. J. and W. E. Collins: Some Influences of Visual Angle and Retinal Speed on Measures of the Spiral Aftereffect, PERCEPTUAL AND MOTOR SKILLS, $30: 215-227,1970$. 
